STUDIA PRAWNO-EKONOMICZNE, t. CIV, 2017

PL ISSN 0081-6841; e-ISSN 2450-8179 s. 269-286

DOI: 10.26485/SPE/2017/104/15

Joanna DZIAŁO*

Bogna GAWROŃSKA-NOWAK**

Ziemowit STAŃCZYK***

\title{
PRAWNO-EKONOMICZNA ANALIZA WYBRANYCH OBSZARÓW TRANSATLANTYCKIEGO PARTNERSTWA HANDLOWO-INWESTYCYJNEGO: MITY CZY REALNE ZAGROŻENIE DLA PAŃSTW SYGNATARIUSZY?
}

\begin{abstract}
(Streszczenie)
Transatlantyckie Partnerstwo Handlowo-Inwestycyjne TTIP jest projektem porozumienia między Stanami Zjednoczonymi a Unią Europejską, które dotyczy czterech ważnych obszarów współpracy: dostęp do rynku, współpraca w zakresie uregulowań prawnych, przepisy i postanowienia instytucjonalne. Treść Traktatu, a zwłaszcza tzw. system ochrony inwestycji, wzbudza szereg kontrowersji i negatywnych emocji wśród opinii publicznej. Co więcej, emocje te dotyczą również oceny spodziewanych skutków ekonomicznych TTIP. Celem niniejszego artykułu jest analiza i ocena najważniejszych kontrowersji narosłych wokół TTIP. Autorzy podjęli także próbę określenia, na ile społeczne oczekiwania dotyczące ekonomicznych korzyści płynących z TTIP znajdują uzasadnienie w tzw. „,wiedzy eksperckiej”. Wydaje się, że rezultaty przeprowadzonej analizy pozwalają na sformułowanie wniosku, że społeczne oczekiwania są zbyt niejednoznaczne, czasami sprzeczne, a z kolei opinie eksperckie zbyt mało czytelne i za mało przekonujące, aby budować właściwy punkt odniesienia.
\end{abstract}

Słowa kluczowe: Transatlantyckie Partnerstwo Handlowo-Inwestycyjne; system ochrony inwestycji; modele CGE; makroekonomiczne efekty TTIP; porozumienie NAFTA

Klasyfikacja JEL: F1, F13, K12, K20, K22, K33, K41

* Dr hab., prof. nadzw., Uczelnia Łazarskiego, Katedra Ekonomii; e-mail: jdzialo@uni.lodz.pl

** Dr hab., prof. nadzw., Uczelnia Łazarskiego, Katedra Ekonomii; e-mail: b.gawronska@lazarski. edu.pl

*** Mgr, Instytut Społeczno-Ekonomicznych Ekspertyz; e-mail: ziemowit@gmx.com 


\section{Wstęp}

Transatlantyckie Partnerstwo Handlowo-Inwestycyjne TTIP(Transatlantic Trade and Investment Partnership) jest projektem porozumienia handlowego między Stanami Zjednoczonymi a Unią Europejską, nadal na etapie negocjacji. Trudności w osiągnięciu globalnego konsensusu w ramach Światowej Organizacji Handlu (dauhańska agenda rozwoju) ${ }^{1}$ skłoniły wiele państw do działania na szczeblu regionalnym, gdzie rozbieżność regulacji krajowych jest mniejsza. W ten sposób zawarto wiele umów o wolnym handlu, z których warto wymienić przynajmniej NAFTA $^{2}$ (North American Free Trade Agreement) oraz TPP ${ }^{3}$ (Trans-Pacific Partnership). Obawa przed marginalizacją Europy w tym procesie konsolidacji regionalnej dodatkowo skłoniła do działania instytucje UE. Negocjacje dwustronne podjęte w 2008 r. z Kanadą zakończyły się sukcesem i CETA ${ }^{4}$ (Comprehensive Economic and Trade Agreement) została podpisana 30 października $2016 \mathrm{r}$.

Celem artykułu jest ocena najważniejszych kwestii związanych z procedura negocjacyjną oraz treścią Traktatu, w tym kontrowersji wokół systemu ochrony inwestycji (Investor State Dispute Settlement), który wzbudza najwięcej negatywnych emocji w opinii publicznej. Ponadto emocje te lokują się wokół oceny spodziewanych skutków ekonomicznych TTIP. Autorzy podejmą zatem próbę określenia, na ile oczekiwania dotyczące ekonomicznych korzyści płynących z TTIP mają realistyczne oparcie w badaniach naukowych. Rezultaty niniejszej analizy mają pomóc w zrozumieniu, w jakim stopniu kontrowersje narosłe wokół TTIP są wynikiem istniejących mitów/stereotypów, a w jakim mają swoje uzasadnienie w faktach.

\section{Treść Traktatu}

TTIP ma zawierać uzgodnienia zebrane w czterech częściach:

- dostęp do rynku,

- współpraca w zakresie uregulowań prawnych,

- przepisy,

- postanowienia instytucjonalne.

T. Łoś-Nowak, Organizacje w stosunkach międzynarodowych - istota, mechanizm działania, zasięg, Wydawnictwo Uniwersytetu Wrocławskiego, Wrocław 2004, s. 29.

2 https://nafta-sec-alena.org/Home/Legal-Texts/North-American-Free-Trade-Agreement

$3 \mathrm{https} / / /$ ustr.gov/trade-agreements/free-trade-agreements/trans-pacific-partnership/tpp-full-text

$4 \mathrm{http}: / /$ eur-lex.europa.eu/legal-content/EN/TXT/?qid=1467909007204\&uri=COM:2016:443:FI$\mathrm{N} \#$ document2 
Dostęp do rynku jest częścią typową dla umów międzynarodowych, na mocy których strony znoszą stawki celne w handlu wzajemnym ${ }^{5}$. Należności celne między Unią Europejską i Stanami Zjednoczonymi wynoszą średnio poniżej $2 \%$, zatem są już bardzo niskie, a ponad połowa handlu między UE a USA nie jest objęta należnościami celnymi. Pomimo to niektóre są wciąż tak wysokie, że w praktyce uniemożliwiają handel ${ }^{6}$. W ramach TTIP miałyby zostać zniesione niemal wszystkie stawki celne. Strony wyrażają też wolę liberalizacji dostępu do swoich rynków usług, ale przy wykluczeniu sektorów wrażliwych, jak telewizja, radio i kinematografia, zdrowie publiczne i edukacja, usługi społeczne, przesył wody. TTIP ma również na celu otwarcie przedsiębiorcom dostępu, na rynkach obu stron, do udziału w publicznych procedurach przetargowych na szczeblach centralnych i lokalnych. Ponadto, porozumienie ma ustanowić zrozumiałe reguły pochodzenia towarów.

Współpraca w zakresie uregulowań prawnych między stronami miałaby miejsce poprzez współdziałanie organów regulacyjnych unijnych i amerykańskich na etapie opracowywania nowych regulacji oraz przeglądu obecnie obowiązujących $^{7}$, co pozwoli na większą spójność przepisów i skuteczniejsze egzekwowanie przyjętych regulacji. W razie braku porozumienia każda ze stron zachowa prawo do osobnych działań normatywnych. Stały organ współpracy regulacyjnej pomagałby w ustaleniu priorytetów i zwiększeniu przejrzystości procesu tej współpracy. Decyzje dotyczące samych regulacji pozostałyby w kompetencji instytucji krajowych. TTIP ma też na celu ograniczenie barier technicznych w handlu, które wynikają ze stosowania różnych wymogów, choć o podobnym poziomie bezpieczeństwa ${ }^{8}$. Barierę taką może stanowić np. ocena zgodności produktu z wymogami technicznymi ${ }^{9}$. Projekt TTIP zawiera też propozycje regulacji bezpieczeństwa żywności oraz zdrowia roślin i zwierzą $t^{10}$. Obecne normy unijne i amerykańskie są w wielu kwestiach rozbieżne mimo podobnego celu: ochrony zdrowia i zaufania społecznego do sektorów rolnego i spożywczego.

Oprócz postanowień horyzontalnych negocjacje obejmują wyznaczone sektory gospodarki w celu ograniczenia powielenia wymogów i określenia programu

5 http://trade.ec.europa.eu/doclib/docs/2015/january/tradoc_153032.pdf

${ }^{6} \mathrm{http} / / /$ trade.ec.europa.eu/doclib/docs/2015/july/tradoc_153659.pdf

7 H. Verdier, Transnational Regulatory Networks and their limits, The Yale Journal of International Law 2009/34, s. 113-172.

8 http://trade.ec.europa.eu/doclib/docs/2015/january/tradoc_153025.pdf

9 J. De Melo, J.-M. Grether, Commerce international : théories et applications, De Boeck Université, 2000, s. 78.

10 http://trade.ec.europa.eu/doclib/docs/2015/january/tradoc_153026.pdf 
przyszłej współpracy między stronami. Sektory te (chemikalia, kosmetyki, przemysł inżynieryjny, technologie informacyjno-komunikacyjne, wyroby medyczne, pestycydy, produkty farmaceutyczne, materiały włókiennicze, pojazdy silnikowe) są obecnie przedmiotem regulacji na tyle odmiennych, że ani harmonizacja, ani wzajemne uznawanie nie są możliwe.

Przepisy zwierają postanowienia o ochronie środowiska ${ }^{11}$ i praw pracowników (zrównoważony rozwój) ${ }^{12}$, o ułatwieniu i zróżnicowaniu dostępu do energii i surowców poprzez stworzenie zbioru przepisów dotyczących handlu i inwestycji w tej dziedzinie ${ }^{13}$. Chodzi też o usprawnienie przepisów celnych i kontroli w celu ułatwienia eksportu. W treści porozumienia są też propozycje ułatwień dla sektora MŚP, głównie chodzi o dostęp do informacji kluczowych dla importu, eksportu i inwestycji.

Przepisy poruszają też kwestię ochrony inwestycji poprzez nadanie inwestorom prawa do wniesienia sprawy do trybunału arbitrażowego (ISDS: investor-state dispute settlement) o rozstrzygnięcie, czy organy jednej ze stron nie potraktowały inwestora zagranicznego z pogwałceniem postanowień TTIP ${ }^{14}$. Strony chcą ponadto ustanowić skuteczny sposób rozstrzygania sporów między nimi, wynikających z TTIP, wykorzystując do tego system stosowany przez Światową Organizację Handlu ${ }^{15}$. TTIP ma też służyć wzmocnieniu ochrony konkurencji poprzez uzgodnienie zasad przejrzystości pomocy publicznej dla przedsiębiorstw i wykluczenie dyskryminacji firm prywatnych przez państwowe posiadające monopol lub szczególne prawa. Ostatni rozdział Przepisów jest poświęcony ochronie praw własności intelektualnej, takich jak patenty, znaki towarowe, wzory, prawo autorskie oraz oznaczenia geograficzne ${ }^{16}$.

Postanowienia instytucjonalne zawarte $\mathrm{w}$ unijnej propozycji negocjacyjnej ${ }^{17}$ mają ustanowić system organów współpracy regulacyjnej między stronami. O ile niektóre z nich mają charakter stricte konsultacyjny (Specialized Committees and Working Group, Domestic Advisory Groups), wliczając w to konsultacje społeczne (Civil Society Forum), naczelna instytucja (Joint Committee) mia-

11 http://trade.ec.europa.eu/doclib/docs/2016/july/tradoc_154800.pdf

$12 \mathrm{http}: / /$ trade.ec.europa.eu/doclib/docs/2015/november/tradoc 153923.pdf

$13 \mathrm{http} / /$ trade.ec.europa.eu/doclib/docs/2016/july/tradoc_154801.pdf

$14 \mathrm{http} / / /$ trade.ec.europa.eu/doclib/docs/2015/january/tradoc_153032.pdf

15 L. Boisson de Chazournes, L'arbitrage à l'OMC, Revue de l'arbitrage ${ }^{\circ}{ }^{3}$, juillet-septembre 2003, s. 950.

16 V. Vangeel, Le rôle des règles d'origine dans le commerce international, Carrefour de l'Economie, 4e année, 2000/3A, s. 14.

17 http://trade.ec.europa.eu/doclib/docs/2016/july/tradoc_154802.pdf 
łaby otrzymać poważniejsze uprawnienia niż tylko nadzór i koordynacja pracy pozostałych organów. Joint Committee miałby prawo wydawania decyzji interpretacyjnych, a jego wykładnia postanowień porozumienia ma być wiążąca dla stron i dla organów roztrzygających spory w ramach ISDS. Drugim interesującym zadaniem Joint Committee byłoby wskazywanie kierunków zmian, jakie strony miałyby wprowadzać do TTIP. O ile sens takich rozwiązań jest wyraźny, o tyle ramy instytucjonalne pozwalające na interpretacje porozumienia poza kontrolą sądową mogą podsycać nieufność opinii publicznej.

\section{Mity/stereotypy versus realne zagrożenia wiązane z TTIP - ujęcie prawne}

Utrzymywanie tajemnicy wokół negocjowanego porozumienia nie budowało zaufania opinii publicznej tak amerykańskiej, jak i europejskiej. Obecnie publiczny dostęp do informacji jest szerszy ${ }^{18}$, mimo to panuje przekonanie, że TTIP ograniczy suwerenność państw w kształtowaniu polityki gospodarczej i społecznej ${ }^{19}$, równając $\mathrm{w}$ dół standardy bezpieczeństwa produktów, ochrony środowiska czy praw pracowników, a nawet wprowadzi równoległy do państwowego system prawny ${ }^{20}$.

Wśród postanowień będących wciąż przedmiotem negocjacji znajdują się trzy kwestie, na których opinia publiczna opiera swój sprzeciw wobec TTIP. Główną z nich jest system ochrony inwestycji. Pozostałe to harmonizacja uregulowań prawnych i standardów oraz współpraca regulacyjna w dziedzinie różnych sektorów gospodarki. Ze względu na ograniczoną objętość artykułu analizie poddane zostaną kontrowersje dotyczące systemu ochrony inwestycji.

\section{System ochrony inwestycji}

Celem regulacji o odpowiedzialności odszkodowawczej państwa za działania jego organów ustawodawczych jest zapewnienie przedsiębiorstwom rekompensaty, w sytuacji gdy zmiana polityki prowadzonej przez władze publiczne przynosi szkodę ich inwestycji. Na skutek decyzji rządu niemieckiego o odejściu od energetyki jądrowej E.ON i RWE zażądały rekompensaty z tytułu poniesionej szkody

$18 \mathrm{http} / /$ info.arte.tv/fr/ttip-transparence-ou-huis-clos

19 J. Adda, Tafta: la souveraineté kidnapée, Alternatives économiques (Dijon), Juin 2016/358, s. 36.

20 http://lemonde.fr/idees/article/2016/09/02/negociations-sur-le-tafta-les-malheurs-du-libreechange_4991548_3232.html 
w poczynionych przez nich inwestycjach w Niemczech ${ }^{21}$. W ramach TTIP odpowiedzialność odszkodowawcza państwa wynikałaby z naruszenia przepisami krajowymi postanowień porozumienia. Jednakże obawy opinii publicznej w niewielkim stopniu odnoszą się do samej zasady odpowiedzialności państwa za przestrzeganie postanowień TTIP. Zarzuty koncentrują się wokół mechanizmu dochodzenia roszczeń przez inwestorów, zwanego ISDS (investor-state dispute settlement).

Tradycja arbitrażu inwestycyjnego sięga końca lat 50. ubiegłego wieku, pierwotnie chodziło o to, by w sprawach o wywłaszczenie inwestorów zagranicznych zagwarantować niezależność organu rozstrzygającego spór od sądownictwa państwa, którego władze podjęły decyzję o wywłaszczeniu ${ }^{22}$. Proponowany system byłby na podobieństwo tych, które funkcjonują w ramach tysięcy traktatów handlowych: inwestor oskarża państwo, w którym ulokował inwestycję przed prywatnym trybunałem arbitrażowym. Najczęściej spotykaną formułąjest trybunał złożony z trzech arbitrów, po jednym wybranym przez każdą ze stron postępowania, a trzeciego strony wybierają zgodnie lub wyznacza go przewodniczący instytucji, gdzie toczyć się ma postępowanie arbitrażowe, najczęściej ICSID (International Centre for Settlement of Investment Disputes) ${ }^{23}$. Aby wygrać sprawę, inwestor musi udowodnić, że państwo naruszyło postanowienia traktatu, wtedy trybunał nakazuje wypłacić na jego rzecz odszkodowanie. Takie rozwiązanie od lat budzi zastrzeżenia z uwagi na ryzyko stronniczości arbitrów, brak mechanizmu apelacji, zmienność stosowanych przez nich definicji i koncepcji prawnych ${ }^{24}$. System powoływania ad hoc zespołu arbitrów, za każdym razem $\mathrm{w}$ innym składzie, stwarzał sytuacje, gdzie przed trybunałem ta sama osoba występowała w jednej sprawie jako adwokat strony, w innej jako arbiter. $\mathrm{W}$ połączeniu z niejawnością postępowania i brakiem dostępu do dokumentacji procesowej prowadziło to do często niebezpodstawnych zarzutów o stronniczość arbitrów i konflikt interesów ${ }^{25}$. Te zarzuty nabierają ciężaru w kontekście braku mechanizmu apelacji od decyzji trybunału arbitrażowego, która w sporze między inwestorem a państwem jest ostateczna. Żaden z obowiązujących obecnie trakta-

${ }^{21} \mathrm{http} / / / \mathrm{dw} . c o m / \mathrm{en} / \mathrm{eon}-$ loses-court-battle-for-nuclear-phase-out-damages/a-19372796

22 A. Fatouros, Government Guarantees to Foreign Investors, Columbia University Press, New York-London 1962, s. 98.

23 https://icsid.worldbank.org/apps/ICSIDWEB/Pages/default.aspx

$24 \mathrm{http} / /$ iisd.org/itn/2012/07/19/analysis-of-the-european-commissions-draft-text-on-investorstate-dispute-settlement-for-eu-agreements/

25 S. Clarkson, Systemic or surgical? Possible Cures for NAFTA's Investor-State Dispute Process. Communication au $31^{\mathrm{e}}$ Workshop on Commercial and Consumer Law, Faculté de Droit, Université de Toronto, 19-20 octobre 2001, s. 121. 
tów handlowych nie przewiduje mechanizmu apelacji, który pełni podwójną rolę: pozwala na korektę nieprawidłowej decyzji wydanej przez pierwszą instancję i zapewnia spójność orzecznictwa.

Zmienność stosowanych definicji i niespójność orzecznictwa nie sprzyjają określeniu równowagi między swobodą państw w kształtowaniu prawa a ich zobowiązaniami wynikającymi z TTIP. Przykładem takiej niespójności są dwie decyzje odrębnych trybunałów, bo powołanych osobno z powództwa różnych inwestorów, ale orzekających w tej samej sprawie przeciwko Gwatemali w 2013 r. Pierwszy trybunał nakazał Gwatemali wypłatę, na rzecz amerykańskiej firmy Teco, rekompensaty za skutki znaczącej obniżki cen ${ }^{26}$. Drugi - oddalił roszczenie hiszpańskiej spółki Iberdrola, uznając, że nie ma kompetencji do orzekania w kwestiach gwatemalskiego prawa ${ }^{27}$.

Orzekając w sporach między państwami a inwestorami, arbitrzy opierają się wyłącznie o postanowienia traktatu z reguły bardziej sprzyjające inwestorom niż pozostałe akty prawne, obowiązujące w kraju miejsca inwestycji. Wiele pojęć kluczowych dla krajowych systemów prawnych, np. „interes publiczny”, jest nieobecnych w porozumieniach handlowych i tym samym w orzecznictwie arbitrażowym ${ }^{28}$. Skoro ratyfikowane umowy międzynarodowe stoją w hierarchii norm wyżej niż ustawy prawa krajowego (art. 91 pkt. 2 konstytucji RP), a orzecznictwo trybunałów arbitrażowych funkcjonuje w pewnej izolacji od krajowych systemów prawnych, może to skłaniać do pytań o ryzyko ograniczania swobody państw w kształtowaniu polityki wewnętrznej.

Postanowienia porozumień handlowych nie uprawniają wprost inwestorów do żądania od państwa, by kształtowało prawo wewnętrzne tak, aby nie stało ono $\mathrm{w}$ sprzeczności z postanowieniami porozumień. Jednakże, duża swoboda interpretacji pozostawiona arbitrom oraz brak czynnika zapewniającego spójność orzecznictwa mogą prowadzić do tego, że inwestor zażąda uchylenia ustawy, która stała się obowiązującym prawem w pozwanym państwie. Tak uczyniła spółka Philip Morris w pozwie przeciwko Australii ${ }^{29}$ na podstawie traktatu o promowaniu i ochronie inwestycji zawartego między tym krajem a Hong Kongiem z 1993 r. Ustawa o jednolitym opakowaniu papierosów, narzucając usunięcie zeń znaku towarowego producenta, naruszała w ocenie inwestora prawo własności intelektualnej.

\footnotetext{
$26 \mathrm{http}: / /$ italaw.com/cases/1629

$27 \mathrm{http}: / /$ investmentpolicyhub.unctad.org/ISDS/Details/347

28 H. Arfazadeh, Ordre public et arbitrage international à l'épreuve de mondialisation, LGDJ, 2005, s. 43.

29 https://pcacases.com/web/view/5
} 
Przegląd procesów prawodawczych w wielu krajach ukazuje tzw. „chilling effect”: władze publiczne, przygotowując projekt regulacji w danej dziedzinie, biora pod uwagę ryzyko sporu z inwestorem przed trybunałem arbitrażowym i koszt odszkodowania (oraz samego postępowania), jaki będą musiały ponieść, po czym - dokonując swoistej autocenzury - odstępują od projektu regulacji ${ }^{30}$. W latach 90. władze Kanady planowały wprowadzić jednolite opakowanie papierosów w ramach polityki walki z uzależnieniem od wyrobów tytoniowych. W liście wysłanym do parlamentarzystów kanadyjskich producent R.J. Reynolds Tobacco zagroził złożeniem pozwu ISDS w ramach traktatu NAFTA. Rząd Kanady odstapił od projektu ustawy ${ }^{31}$. Na skutek wspomnianego pozwu, złożonego przez Philipp Morris przeciwko Australii, także i władze Nowej Zelandii zawiesiły prace nad stosowną ustawą.

Koszt sporu między inwestorem a państwem może też skłaniać instytucje publiczne do rozwiązań polubownych. W 2010 r. organ ds. ochrony środowiska w Hamburgu obniżył normy ekologiczne, jakie miała spełniać elektrownia węglowa budowana przez szwedzki koncern Vattenfall ${ }^{32}$, w zamian za wycofanie skargi przeciwko Niemcom przed trybunałem arbitrażowym na kwotę 4 mld EUR ${ }^{33}$.

Pozew ISDS może być z zasady złożony przeciwko wszystkim szczeblom administracyjnym państwa, inaczej mówiąc, nawet uchwała rady miasta może być przedmiotem sporu z inwestorem. „Chilling effect” w postaci ryzyka obciążenia budżetu kosztami odszkodowania skutecznie skłoniłoby władze lokalne do prowadzenia pasywnej polityki, potencjalnie w sprzeczności z interesem publicznym ${ }^{34}$. ISDS w kształcie proponowanym przez negocjatorów TTIP może zatem być postrzegany jako narzędzie wywierania pośrednio wpływu przez inwestorów na politykę wewnętrzną państw członkowskich UE, ale i na politykę unijną.

W 2015 r. negocjatorzy europejscy przedstawili propozycję Investment Court System (ICS). Miałby to być dwuinstancyjny system sądu publicznego o stałym charakterze. Zasiadaliby tam zawodowi sędziowie, opłacani z funduszu założonego specjalnie na ten cel przez strony TTIP (zamiast przez powód i pozwanego). Ponadto, wybór składu sędziowskiego byłby dokonywany drogą losowania,

${ }^{30} \mathbf{K}$. Tienhaara, Regulatory chill and the threat of arbitration: A view from political science, w: Evolution in Investment Treaty Law and Arbitration, Cambridge University Press, 2011, s. 607.

31 http://jurist.org/forum/2011/12/allyn-taylor-tobacco-suit.php

$32 \mathrm{http} / /$ corporatedisputesmagazine.com/vattenfall-v-germany-ii-and-the-familiar-irony-of-isdsinvestors-before-public-interest/

33 https://iisd.org/pdf/2009/background_vattenfall_vs_germany.pdf

$34 \mathrm{http} / / /$ citizen.org/documents/ustr-isds-response.pdf, s. 17. 
osobnego do każdej sprawy (w ISDS arbitrów wybierają strony sporu). Od orzeczenia sądu przysługiwałoby prawo do wniesienia apelacji rozpatrywanej przez sąd w innym i dwukrotnie szerszym składzie. Propozycja ogranicza też zakres uprawnionych roszczeń inwestorów poprzez klauzulę o ,prawie państwa do podejmowania środków dla realizacji słusznych celów polityki publicznej" czy zapis stanowiący, że restrukturyzacja długu publicznego nie może być przedmiotem roszczenia. Przyjęcie propozycji europejskiej usunęłoby przesłanki, na jakich oparte są obawy opinii publicznej co do zamachu inwestorów na suwerenność państw w kształtowaniu polityki wewnętrznej ${ }^{35}$.

Modelem systemu rozwiązywania sporów między inwestorem a państwem może stać się mechanizm przyjęty przez Kanadę i Unię Europejskę w ramach CETA $^{36}$ - stały trybunał o charakterze instytucji publicznej, sędziowie wybierani losowo do każdej sprawy, otrzymujący wynagrodzenie od stron traktatu, możliwość wniesienia apelacji, obowiązek wydania orzeczenia w terminie 24 miesięcy, klauzule gwarantujące państwom prawo do zmiany przepisów wewnętrznych ${ }^{37}$.

\section{Mity/stereotypy wokół makroekonomicznych efektów TTIP versus opinie ekspertów}

W badaniu opracowanym przez YouGov na zlecenie Fundacji Bertelsmanna w 2016 r. przedstawiono oczekiwania obywateli wobec wpływu TTIP na gospodarkę i społeczeństwo. Kwestionariusz dostępny internetowo wypełniło 1126 obywateli amerykańskich oraz 2019 obywateli niemieckich. Wyniki badania prezentuje tabela 1.

Należy zauważyć, że na tle podanych 11 kategorii szczególnie trzy pierwsze mają charakter makroekonomiczny. Wydaje się, że odczucia respondentów co do roli czynników makro w definiowaniu przyszłości związanej z wprowadzeniem TTIP są dość ambiwalentne, jednak z lekką przewagą rokowań pozytywnych. Nieco bardziej liczą na pobudzenie wzrostu gospodarczego na skutek TTIP Amerykanie (29\%) niż Niemcy (27\%) i jest to u nich drugi czynnik (zaraz po „zyskiwaniu wpływu twojego kraju na świat”) pod względem ważności dla odsetka osób wykazujących percepcję pozytywną. Niemcy zaś najwyżej (spośród

35 S. Spears, The Question for Policy Space in a New Generation of International Investment Agreements, Journal of International Economic Law 2010/1037, s. 26.

$36 \mathrm{http} / / /$ trade.ec.europa.eu/doclib/docs/2014/september/tradoc_152806.pdf

37 https://mediapart.fr/journal/economie/010316/libre-echange-l-accord-avec-le-canada-fait-ungrand-bond-en-avant?onglet=full 
wszystkich 11 kategorii) dobrze oceniają swoje szanse na zwiększenie międzynarodowej konkurencyjności oraz pobudzenie wzrostu gospodarczego, gdyby TTIP zaczęło obowiązywać. Jeśli chodzi o ocenę wpływu TTIP na zatrudnienie i rynek pracy, to jest ona negatywna i u Niemców, i u Amerykanów. Jednak nawet te wysoko pozycjonowane na liście dobrych oczekiwań makroefekty, jak i ta ostatnia z wymienionych kategorii, rodząca większość złych skojarzeń nie są w stanie przebić u Niemców niechęci wobec TTIP ze względu na „ochronę praw konsumentów”, „standardy dotyczące środowiska naturalnego” czy „prawa pracownicze”. U Amerykanów nie ma tak zdecydowanych postaw - ani „,na nie”, ani „,na tak". Trudno też nie zauważyć, że zarówno wśród respondentów niemieckich, jak i amerykańskich (zdecydowanie więcej takich postaw w USA) widoczny jest brak dominujących stanowisk i oprócz dość ekwiwalentnie znoszących się skrajnych poglądów sporą grupę stanowią osoby deklarujące swoją neutralność oraz te niedysponujące odpowiednią znajomością tematu. Brak wiedzy jest szczególnie mocno obecny w deklaracjach amerykańskich respondentów.

TABELA 1: Rozkład odpowiedzi na pytanie: Jak twoim zdaniem TTIP wplynie na wymienione kategorie? $(w \%)$

\begin{tabular}{|l|c|c|c|c|c|c|c|c|}
\hline \multirow{2}{*}{ Kategorie badawcze } & \multicolumn{4}{|c|}{ Niemcy } & \multicolumn{4}{c|}{ Stany Zjednoczone } \\
\cline { 2 - 10 } & $\begin{array}{c}\text { pozytyw- } \\
\text { nie }\end{array}$ & $\begin{array}{c}\text { nega- } \\
\text { tywnie }\end{array}$ & $\begin{array}{c}\text { neu- } \\
\text { tralnie }\end{array}$ & $\begin{array}{c}\text { nie } \\
\text { wiem }\end{array}$ & $\begin{array}{c}\text { pozytyw- } \\
\text { nie }\end{array}$ & $\begin{array}{c}\text { nega- } \\
\text { tywnie }\end{array}$ & $\begin{array}{c}\text { neu- } \\
\text { tralnie }\end{array}$ & $\begin{array}{c}\text { nie } \\
\text { wiem }\end{array}$ \\
\hline Wzrost gospodarczy & 27 & 26 & 19 & 28 & 29 & 23 & 8 & 39 \\
\hline $\begin{array}{l}\text { Zatrudnienie i warunki } \\
\text { rynku pracy }\end{array}$ & 23 & 28 & 22 & 28 & 21 & 27 & 11 & 41 \\
\hline $\begin{array}{l}\text { Międzynarodowa } \\
\text { konkurencyjność }\end{array}$ & 29 & 24 & 19 & 28 & 24 & 22 & 11 & 43 \\
\hline $\begin{array}{l}\text { Wpływ twojego kraju } \\
\text { na świat }\end{array}$ & 23 & 21 & 26 & 29 & 31 & 15 & 16 & 38 \\
\hline Ochrona konsumenta & 12 & 48 & 13 & 27 & 23 & 22 & 12 & 43 \\
\hline Standardy ekologiczne & 12 & 46 & 16 & 27 & 18 & 19 & 29 & 44 \\
\hline Prawa pracownicze & 10 & 40 & 22 & 29 & 17 & 24 & 15 & 45 \\
\hline Różnorodność kulturowa & 24 & 17 & 30 & 28 & 26 & 12 & 22 & 39 \\
\hline Usługi publiczne & 10 & 27 & 31 & 31 & 15 & 13 & 26 & 46 \\
\hline Demokracja & 10 & 28 & 32 & 29 & 20 & 14 & 23 & 43 \\
\hline $\begin{array}{l}\text { Niezależność } \\
\text { w stanowieniu prawa }\end{array}$ & 9 & 37 & 22 & 32 & 17 & 22 & 15 & 47 \\
\hline
\end{tabular}

Ź r ó d ł o: Raport z badania Fundacji Bertelsmanna: „Attitudes to global trade and TTIP in Germany and United States", https://www.bertelsmannstiftung.de/fileadmin/files/BSt/Publikationen/ GrauePublikationen/NW_Attitudes_global_trade_and_TTIP.pdf, s. 18. 
W ramach „twardych” analiz ex-ante makroekonomiczne efekty TTIP szacowane są z wykorzystaniem stosowanych modeli równowagi ogólnej (ang. computable general equilibrium models - CGE). Wszystkie te modele operuja perspektywą ,globalną” i eksplorują bazę danych GTAP (Global Trade Analysis Project), w której są informacje zgromadzone dla 113 krajów i 57 sektorów gospodarki ${ }^{38}$. Komisja Europejska (KE) wyraźnie podkreśla, że pomimo świadomości pewnych wad modeli CGE uważa to podejście za jedyne wiarygodne dla potrzeb określania efektów TTIP. Wyniki uzyskane przez Centre for Economic Policy Research ustanawiają tutaj niepodważalny - dla KE - kanon. Istnieją jeszcze inne opracowania: Berden, Francois, Thelle, Wymenga i Tamminen (ECORYS $)^{39}$; Fontagne, Gourdon, Jean (CEPII) ${ }^{40}$; Felbermayr, Heid i Lehwald $(\text { Bertelsmann/IF) })^{41}$ oraz Egger, Francois, Manchin i Nelson ${ }^{42}$. Zbiorcze wyniki tych analiz przedstawia tabela 2 .

TABELA 2: Porównanie wyników modeli ex-ante

\begin{tabular}{|l|c|c|c|c|c|}
\hline \multirow{2}{*}{ Typ modelu } & $\begin{array}{c}\text { Ecorys, } \\
2009\end{array}$ & $\begin{array}{c}\text { CEPII, } \\
2013\end{array}$ & $\begin{array}{c}\text { CEPR, } \\
2013\end{array}$ & $\begin{array}{c}\text { Bertelsmann/IFO, } \\
2013\end{array}$ & $\begin{array}{c}\text { Egger i inni, } \\
2015\end{array}$ \\
\cline { 2 - 7 } & CGE & $\begin{array}{c}\text { CGE } \\
\text { (MIRAGE) }\end{array}$ & CGE & $\begin{array}{c}\text { połączenie mode- } \\
\text { lu grawitacyjnego } \\
\text { z CGE }\end{array}$ & $\begin{array}{c}\text { połączenie } \\
\text { modelu gra- } \\
\text { witacyjnego } \\
\text { z CGE }\end{array}$ \\
\hline Baza danych & GTAP 7 & GTAP & GTAP 8 & nie sprecyzowano & GTAP 9 \\
\hline Okres prognozy & $2008-2018$ & $2015-2025$ & $2017-2027$ & $10-20$ lat & $10-20$ lat \\
\hline \multicolumn{7}{|c|}{ Zmiana w \% } \\
\hline $\begin{array}{l}\text { Prognozowany } \\
\text { PKB dla UE }\end{array}$ & $0,35-0,72$ & $0,0-0,5$ & $0,02-0,48$ & $0,52-1,31$ & $0,1-1,14$ \\
\hline $\begin{array}{l}\text { Prognozowany } \\
\text { PKB dla USA }\end{array}$ & $0,14-0,31$ & $0,0-0,5$ & $0,01-0,39$ & $0,35-4,82$ & $0,13-0,88$ \\
\hline $\begin{array}{l}\text { Bilateralny } \\
\text { eksport UE }\end{array}$ & $\begin{array}{c}\text { nie sprecy- } \\
\text { zowano }\end{array}$ & 49,0 & $0,69-28,0$ & $5,7-68,8$ & $\begin{array}{c}\text { nie sprecyzo- } \\
\text { wano }\end{array}$ \\
\hline
\end{tabular}

38 Kolejne cyfry przy dostępnych i zastosowanych w badaniu wersjach baz danych GTAP określają stopień ich aktualności (wersja 9 jest bardziej aktualna niż 8; w wersji 8 rokiem bazowym jest 2007, w wersji 9 rok 2011).

39 K.G. Berden, J. Francois, M. Thelle, P. Wymenga, S. Tamminen, Non-tariff measures in EU-US trade and investment - An economic analysis, ECORYS Nederland BV, Rotterdam 2009.

40 L. Fontagné, J. Gourdon, S. Jean, Transatlantic trade: whither partnership, which economic consequences?, CEPII Policy Brief 2013/1.

${ }^{41}$ G. Felbermayr, H. Benedict, L. Sybille, Transatlantic Trade and Investment Partnership (TTIP). Who benefits from a free trade deal, Global Economic Dynamics 2013.

42 P. Egger, J. Francois, M. Manchin, N.D. Nelson, Non-tariff barriers, integration and the transatlantic economy, Economic Policy 2015/30 (83). 


\begin{tabular}{|l|c|c|c|c|c|}
\hline \multirow{2}{*}{ Typ modelu } & $\begin{array}{c}\text { Ecorys, } \\
2009\end{array}$ & $\begin{array}{c}\text { CEPII, } \\
2013\end{array}$ & $\begin{array}{c}\text { CEPR, } \\
2013\end{array}$ & $\begin{array}{c}\text { Bertelsmann/IFO, } \\
2013\end{array}$ & $\begin{array}{c}\text { Egger i inni, } \\
2015\end{array}$ \\
\cline { 2 - 6 } & CGE & $\begin{array}{c}\text { CGE } \\
\text { (MIRAGE) }\end{array}$ & CGE & $\begin{array}{c}\text { połączenie mode- } \\
\text { lu grawitacyjnego } \\
\text { z CGE }\end{array}$ & $\begin{array}{c}\text { połączenie } \\
\text { modelu gra- } \\
\text { witacyjnego } \\
\text { z CGE }\end{array}$ \\
\hline $\begin{array}{l}\text { Płace realne } \\
\text { w UE }\end{array}$ & $0,34-0,78$ & brak danych & $0,29-0,51$ & nie sprecyzowano & $\begin{array}{c}\text { nie sprecyzo- } \\
\text { wano }\end{array}$ \\
\hline $\begin{array}{l}\text { Stopa bezro- } \\
\text { bocia w UE } \\
\text { (średnia) }\end{array}$ & $\begin{array}{c}\text { niezmie- } \\
\text { niona } \\
\text { (założenie) }\end{array}$ & $\begin{array}{c}\text { niezmienio- } \\
\text { na (założe- } \\
\text { nie) }\end{array}$ & $\begin{array}{c}\text { niezmieniona } \\
\text { (założenie) }\end{array}$ & $\begin{array}{c}-0,42 \text { (dla wa- } \\
\text { riantu głębokiej } \\
\text { liberalizacji }\end{array}$ & $\begin{array}{c}\text { niezmieniona } \\
\text { (założenie) }\end{array}$ \\
\hline
\end{tabular}

Ź r ó d ł o: W. Raza, W.J. Grumiller, L. Taylor, B. Tröster, R. Arnim, Assessing the claimed benefits of the transatlantic trade and investment partnership, Policy Note 2014/10, s. 2 oraz P. Egger, P.J. Francois, M. Manchin, D. Nelson, Non-tariff barriers, integration and the transatlantic economy, Economic Policy 2015/30(83).

W podsumowaniu dorobku tych opracowań można stwierdzić, że prognozowane na ich podstawie makroekonomiczne efekty TTIP dla europejskich gospodarek są pozytywne bez względu na wariant liberalizacji. Ich pozytywny wydźwięk ulega wzmocnieniu przy zwiększeniu stopnia liberalizacji. Jednocześnie krytycznie patrząc na uzyskane wyniki, nie sposób nie zauważyć, że skala korzyści nie jest imponująca, zwłaszcza jeśli odnieść ją do relatywnie długiego przedziału czasu, w jakim korzyści te miałyby wystapić. Tak zwane analizy krajowe (bazujące na modelach dla pojedynczych gospodarek) na ogół wykazuja jeszcze mniejszą skalę korzyści ${ }^{43}$. Wysuwane są także zastrzeżenia dotyczące możliwości wystąpienia efektu przesunięcia handlu (ang. trade diversion). Zgodnie z rezultatami symulacji otrzymanymi przez Felbermayra, Heida i Lehwalda ${ }^{44}$, eliminacja opłat taryfowych w ramach TTIP najdotkliwiej doświadczy kraje rozwijające się. Kraje te będą musiały stawić czoła malejącym udziałom w rynkach globalnych w związku ze wzrastającą presją konkurencyjną na rynkach UE i USA. Realokacja wpływów może okazać się trudna ze względu na dużą

${ }^{43}$ Zobacz np. opracowania dla Polski: K. Hagemejer, Liberalization of trade flows under TTIP from a small country perspective. The case of Poland, Working Papers (No. 2015-17), Uniwersytet Warszawski Warszawa 2015; M. Przybyliński, Wplyw TTIP na Polske (analiza input-output) wstepne szacunki, wystapienie na konferencji: The Impact of the Transatlantic Trade And Investment Partnership (TTIP) on International Cooperation - Conclusions for Eu Members From Central And Eastern Europe, Warszawa 30 listopada - 1 grudnia 2015, http:// kolegia.sgh.waw.pl/pl/ KGS/struktura/IMSG/konferencje/Documents/Przybylinski.pdf

${ }^{44}$ G. Felbermayr, B. Heid, S. Lehwald, Transatlantic Trade and Investment Partnership (TTIP). Who benefits from a free trade deal, Global Economic Dynamics 2013, s. 19. 
odległość alternatywnych lokalizacji - w szczególności mogą to odczuć kraje Północnej i Zachodniej Afryki, tradycyjnie silnie związane z Europą, a potencjalnie wypierane - po wprowadzeniu TTIP - przez USA.

Raza, Grumiller, Taylor, Tröster i Von Arnim ${ }^{45}$ podkreślają, że w analizach opartych na modelach CGE koszty dostosowawcze są zaniżane lub wręcz nieuwzględniane (szacunkowo 33-60 miliardów euro w okresie 10 lat). Jeśli zaś chodzi o koszty dla budżetów gospodarek europejskich, to będą one musiały ponieść straty z tytułu utraconych przychodów z opłat taryfowych, co zwiększy deficyty fiskalne. W 2012 r. 12\% przychodów do unijnego budżetu stanowiły wpływy z tytułu taryf. Zwolennicy TTIP podkreślaja, że wpływy z tytułu rosnącego eksportu mają rekompensować te straty. Jednak należy zauważyć, że dynamika wzrostu eksportu wykazuje powolną tendencję, podczas gdy odcięcie od wpływów taryfowych nastapi od razu.

Biorąc pod uwagę podnoszone wątpliwości, posłużenie się przykładem Północnoamerykańskiego Porozumienia o Wolnym Handlu (NAFTA), jako ważnym punktem odniesienia dla oceny potencjalnych makroefektów TTIP, wydaje się bardzo trafne. NAFTA funkcjonuje bowiem już od 22 lat, co daje historycznie bogatą perspektywę porównawczą, oczywiście ograniczoną ze względu na różnice co do samego zakresu obydwu porozumień (TTIP i NAFTA). Większość badań ex-ante poświęcona NAFTA przewidywała wzrost realnego PKB w USA od $0,1 \%$ do $0,3 \%$. Wyniki analiz były natomiast znacznie bardziej optymistyczne dla Meksyku, gdyż przewidywały wzrost realnego PKB powyżej 2\%. Jeśli chodzi o badania empiryczne dotyczące wpływu NAFTA na PKB Kanady, to są one nieliczne i mocno zróżnicowane ${ }^{46}$. Generalnie, w świetle prowadzonych badań średni wzrost PKB wynosił 0,14\% w przypadku USA, 2,27\% dla Meksyku oraz $1,1 \%$ w przypadku Kanady.

Konfrontacja przedstawionych projekcji ex-ante z wynikami analiz ex-post wpływu NAFTA na wyniki makroekonomiczne USA, Meksyku i Kanady wskazuje jednoznacznie, że rzeczywisty wpływ NAFTA na gospodarki wspomnianych krajów był znacznie niższy niż przewidywany w projekcjach. Na przykład Caliendo i Parro oszacowali skutki zawarcia umowy NAFTA w odniesieniu do realnego PKB w okresie 1993-2005 na poziomie 0,08\% w przypadku Stanów

\footnotetext{
${ }^{45}$ W. Raza, W.J. Grumiller, L. Taylor, B. Tröster, R. Arnim, Assessing the claimed benefits of the transatlantic trade and investment partnership, Policy Note 2014/10, s. 24-39.

${ }^{46}$ Zobacz np. D. Cox, R. Harris, North American Free Trade and its Implications for Canada: Results from a CGE Model of North American Trade, The World Economy 1992/15/1, s. 39 oraz D. Roland-Holst, K. Reinert, C. Shiells, NAFTA Liberalization and the Role of Nontariff Barriers, North American Journal of Economics \& Finance 1994/5/2, s. 151.
} 
Zjednoczonych, 1,31\% dla Meksyku i-0,06\% dla Kanady. Jednocześnie podkreślić należy, że są to najbardziej optymistyczne oszacowania, a mimo to plasują się znacznie poniżej wcześniejszych projekcji.

Po ponad 20 latach istnienia NAFTA w ogólnym podsumowaniu można zaryzykować stwierdzenie, że największe korzyści z NAFTA odnosi Kanada, główny eksporter dóbr do USA. Z perspektywy kanadyjskiej najwięcej skorzystały wielkie firmy, zwłaszcza wielki przemysł energetyczny, gdyż dzięki układowi może bez ograniczeń przesyłać nośniki energii do USA. Ponadto, korzyści odniósł także meksykański biznes i całe społeczeństwo, bo chociaż płace w Meksyku nie wzrosły, to doszło do spadku cen ubrań, żywności i elektroniki. NAFTA przyczyniła się również do wzrostu wymiany handlowej między państwami członkowskimi z 290 mld w 1993 r. do 1,6 mld w 2012 r. Zanotowano wzajemny dynamiczny wzrost inwestycji oraz wymiany turystycznej.

\section{Zakończenie}

Pobudzenie wymiany handlowej między Stanami Zjednoczonymi a krajami Unii Europejskiej oraz stymulacja inwestycji po obu stronach Atlantyku stanowią cele nie do przecenienia, ich osiagnięcie wymaga jednak nie tylko kompromisu przedstawicieli obu stron, ale także legitymacji ze strony opinii publicznej. Warto zauważyć, że bardziej skonkretyzowane oczekiwania społeczne, np. wobec skutków ekonomicznych TTIP, mogłyby odegrać co najmniej rolę katalizatora woli politycznej i niezbędnych działań, zmierzających do zawarcia umowy. Jednak oczekiwania te wydają się być niejasne, często sprzeczne, a opinie naukowe prawdopodobnie mało czytelne i przekonujące (skomplikowany język modeli, dość umiarkowane scenariusze korzyści), by budować niezbędny i przeważający punkt odniesienia.

Wydaje się, że większość obaw dominujących w dyskursie publicznym jest oparta na doświadczeniach innych regionalnych porozumień handlowych (np. NAFTA), które niosą ze sobą niejednoznacznie pozytywny przekaz. Dlatego treść Transatlantyckiego Partnerstwa Handlowo-Inwestycyjnego powinna stanowić nowy standard, wyróżniający się pośród obowiązujących już traktatów handlowych. Ta wyjątkowość musiałaby polegać nie tylko na nadaniu przez strony nadrzędnej wartości normom jakości i bezpieczeństwa towarów, przepisom ochrony środowiska i ochrony praw pracowniczych, ale także na uzgodnieniu skutecznych mechanizmów prawnych służących tej nadrzędności. 


\section{Bibliografia}

\section{Akty prawne}

Comprehensive Economic and Trade Agreement (CETA).

North American Free Trade Agreement (NAFTA).

Treaty on European Union, OJ EU 2016 C 202.

Treaty on the Functioning of the European Union, OJ EU 2016 C 202, s. 47.

Trans-Pacific Partnership (TPP).

\section{Orzecznictwo/Case Law}

Clayton/Bilcon v. Government of Canada, UNCITRAL, (Award on jurisdiction and liability 17 of March 2015), Permanent Court of Arbitration (PCA) Case No. 2009-04.

Ethyl Corporation $v$. The Government of Canada, UNCITRAL, (Award on Jurisdiction of 24 June 1998).

Iberdrola Energía S.A. v. Republic of Guatemala, (Award of 17 August 2012), ICSID Case No. ARB/09/5.

Philip Morris Asia Limited v. Commonwealth of Australia, UNCITRAL, PCA Case No. 2012-12.

TECO Guatemala Holdings, LLC v. Guatemala (Award of 19 December 2013), ICSID Case No. ARB/10/23.

United States - Certain Country of Origin Labelling (Cool) Requirements, (Complainant: Canada), WTO dispute settlement (ds384).

United States - Measures Affecting the Production and Sale of Clove Cigarettes, Complainant: Indonesia), WTO dispute settlement (ds406).

Vattenfall AB and others v. Federal Republic of Germany, ICSID Case No. ARB/12/12.

\section{Opracowania}

Attitudes to global trade and TTIP in Germany and United States, Fundacja Bartelsmann, Raport, https://www.bertelsmannstiftung.de/fileadmin/files/BSt/Publikationen/GrauePublikationen/ NW_Attitudes_global_trade_and_TTIP.pdf

Adda Jacques, Tafta: la souveraineté kidnapée, Alternatives économiques (Dijon), Juin 2016/358.

Arfazadeh Homayoon, Ordre public et arbitrage international à l'épreuve de mondialisation, LGDJ, 2005.

Berden Koen G., Francois Joseph, Thelle Martin, Wymenga Paul, Tamminen Sara, Nontariff measures in EU-US trade and investment - An economic analysis, ECORYS Nederland BV Rotterdam 2009.

Boisson de Chazournes Laurence, L'arbitrage à l' $O M C$, Revue de l'arbitrage $\mathrm{n}^{\circ} 3$, juillet-septembre 2003.

Brower Charles N., Schill Stephan W., Is Arbitration a Threat of a Boon to the Legitimacy of International Investment Law?, Chicago Journal of International Law 2009/9.

Clarkson Stephen, Systemic or surgical? Possible Cures for NAFTA's Investor-State Dispute Process. Communication au 31e Workshop on Commercial and Consumer Law, Faculté de Droit, Université de Toronto, 19-20 octobre 2001.

Cox David, Harris Richard G., North American Free Trade and its Implications for Canada: Results from a CGE Model of North American Trade, The World Economy 1992/15/1. 
Dehousse Franklin, Vincent Philippe, Les règles d'origine de la Communauté européenne. Pratique du droit communautaire, Bruylant, Bruxelles 1999.

De Melo Jaime, Grether Jean-Marie, Commerce international : théories et applications, De Boeck Université, 2000.

Dolzer Rudolf, Stevens Margrete, Bilateral Investment Treaties, Martinus Nijhoff Publishers, Boston 1995.

Egger Peter, Francois Joseph, Manchin Miriam, Nelson N. Douglas, Non-tariff barriers, integration and the transatlantic economy, Economic Policy 2015/30 (83).

Fatouros Angelica, Government Guarantees to Foreign Investors, Columbia University Press, New York-London 1962.

Felbermayr Gabriel, Heid Benedict, Lehwald Sybille, Transatlantic Trade and Investment Partnership (TTIP). Who benefits from a free trade deal, Global Economic Dynamics 2013.

Fontagné Louis, Gourdon James, Jean Sean, Transatlantic trade: whither partnership, which economic consequences?, CEPII Policy Brief 2013/1.

Hagemejer Krzysztof, Liberalization of trade flows under TTIP from a small country perspective. The case of Poland, Working Papers (No. 2015-17), Uniwersytet Warszawski 2015.

Loś-Nowak Teresa, Organizacje w stosunkach międzynarodowych - istota, mechanizm działania, zasięg, Wydawnictwo Uniwersytetu Wrocławskiego, Wrocław 2004.

Mann Howard, Private Rights, Public Problems: A Guide to NAFTA's Controversial Chapter on Investor Rights, International Institute for Sustainable Development, 2001.

Przybyliński Michal, Wpływ TTIP na Polske (analiza input-output) wstępne szacunki, wystapienie na konferencji: The Impact of the Transatlantic Trade And Investment Partnership (TTIP) on International Cooperation - Conclusions for Eu Members From Central And Eastern Europe, Warszawa 30 listopada - 1 grudnia 2015, http://kolegia.sgh.waw.pl/pl/KGS/struktura/ IMSG/konferencje/Documents/Przybylinski.pdf

Raza Werner, Grumiller Jan, Taylor Lance, Tröster Bernhard, Arnim Rudi von, Assessing the claimed benefits of the transatlantic trade and investment partnership, Policy Note 2014/10.

Roland-Holst David, Reinert Kenneth A., Shiells Clinton R., NAFTA Liberalization and the Role of Nontariff Barriers, North American Journal of Economics \& Finance 1994/5/2.

Spears Suzanne A., The Quest for Policy Space in a New Generation of International Investment Agreements, Journal of International Economic Law 2010/1037.

Tienhaara Kyla, Regulatory chill and the threat of arbitration: A view from political science, w: Evolution in Investment Treaty Law and Arbitration, Cambridge University Press, 2011.

Van Geel Valère, Le rôle des règles d'origine dans le commerce international, Carrefour de l'Economie, 4e année, 2000/3A.

Verdier Pierre-Hugues, Transnational Regulatory Networks and their limits, The Yale Journal of International Law 2009/34.

\section{Strony internetowe}

http://citizen.org/documents/ustr-isds-response.pdf; stan na 23.09.2016 r.

$\mathrm{http}$ //corporatedisputesmagazine.com/vattenfall-v-germany-ii-and-the-familiar-irony-of-isdsinvestors-before-public-interest/; stan na 25.09.2016 r.

$\mathrm{http} / / /$ data.consilium.europa.eu/doc/document/ST-11103-2013-DCL-1/en/pdf; stan na 23.09.2016 r. http:/eur-lex.europa.eu/legal-content/EN/TXT/?qid=1467909007204\&uri=COM:2016:443:FI-

N\#document2; stan na 25.09.2016 r. 
http://eur-lex.europa.eu/legal-content/FR/TXT/?uri=URISERV\%3Aai0034; stan na 25.09.2016 r. https://icsid.worldbank.org/apps/ICSIDWEB/Pages/default.aspx; stan na 03.11.2016 r.

http://iisd.org/itn/2012/07/19/analysis-of-the-european-commissions-draft-text-on-investorstate-dispute-settlement-for-eu-agreements/; stan na 27.09.2016 r.

https://iisd.org/pdf/2009/background_vattenfall_vs_germany.pdf; stan na 27.09.2016 r. http://info.arte.tv/fr/ttip-transparence-ou-huis-clos; stan na 03.11.2016 r. http://investmentpolicyhub.unctad.org/ISDS/Details/304; stan na 01.10.2016 r. http://investmentpolicyhub.unctad.org/ISDS/Details/347; stan na 01.10.2016 r. $\mathrm{http}: / /$ italaw.com/cases/1629; stan na 03.10.2016 r. http://jurist.org/forum/2011/12/allyn-taylor-tobacco-suit.php; stan na 03.10.2016 r. http://lemonde.fr/idees/article/2016/09/02/negociations-sur-le-tafta-les-malheurs-du-libreechange_4991548_3232.html; stan na 09.10.2016 r.

https://mediapart.fr/journal/economie/010316/libre-echange-1-accord-avec-le-canada-fait-ungrand-bond-en-avant?onglet=full; stan na 08.10.2016 r.

https:/ /nafta-sec-alena.org/Home/Legal-Texts/North-American-Free-Trade-Agreement; stan na 08.10.2016 r.

https://pcacases.com/web/view/5; stan na 12.10.2016 r.

http://trade.ec.europa.eu/doclib/docs/2015/january/tradoc_153032.pdf; stan na 13.10.2016 r. http://trade.ec.europa.eu/doclib/docs/2015/july/tradoc_153659.pdf; stan na 14.10.2016 r. http://trade.ec.europa.eu/doclib/docs/2015/january/tradoc_153025.pdf; stan na 14.10.2016 r. http://trade.ec.europa.eu/doclib/docs/2015/january/tradoc_153026.pdf; stan na 10.10.2016 r. http://trade.ec.europa.eu/doclib/docs/2016/july/tradoc_154800.pdf; stan na 16.10.2016 r. http://trade.ec.europa.eu/doclib/docs/2015/november/tradoc_153923.pdf; stan na 16.10.2016 r. http://trade.ec.europa.eu/doclib/docs/2016/july/tradoc_154801.pdf; stan na 24.10.2016 r. http://trade.ec.europa.eu/doclib/docs/2015/january/tradoc_153032.pdf; stan na 24.10.2016 r. http://trade.ec.europa.eu/doclib/docs/2016/july/tradoc_154802.pdf; stan na 24.10.2016 r. http://trade.ec.europa.eu/doclib/docs/2014/september/tradoc_152806.pdf; stan na 01.10.2016 r. http://trade.ec.europa.eu/doclib/docs/2016/march/tradoc_154377.pdf; stan na 03.11.2016 r. http://trade.ec.europa.eu/doclib/docs/2016/july/tradoc_154795.pdf; stan na 02.11.2016 r. https://ustr.gov/trade-agreements/free-trade-agreements/trans-pacific-partnership/tpp-full-text; stan na 03.11.2016 r.

https:/wto.org/english/tratop_e/dispu_e/cases_e/ds406_e.htm; stan na 03.11.2016 r.

Joanna DZIAŁO

Bogna GAWROŃSKA-NOWAK

Ziemowit STAŃCZYK

\section{LEGAL AND ECONOMIC ANALYSIS OF SELECTED AREAS OF THE TRANSATLANTIC TRADE AND INVESTMENT PARTNERSHIP: MYTHS OR A REAL THREAT TO THE SIGNATORY COUNTRIES?}

( Sum mary)

Transatlantic Trade and Investment Partnership is a proposed agreement between the United States and the European Union, which concerns four important areas of cooperation: market access, cooperation in the field of legislation, regulations and institutional provisions. The content of the 
Treaty, and especially the so-called investment protection system, causes a number of controversies and negative emotions among the public. Moreover, these emotions relate to the assessment of the expected economic impact of the TTIP. The purpose of this article is to analyze and evaluate major controversies around the TTIP. The authors have also attempted to determine how social expectations about the economic benefits of TTIP are justified in the so-called "expertise" knowledge. It seems that the results of the analysis allow to conclude that social expectations are rather ambiguous, sometimes contradictory and expert opinions are rather unclear and not convincing to build an appropriate benchmark.

Keywords: Transatlantic Trade and Investment Partnership; investment protection system; CGE models; macroeconomic effects of TTIP; NAFTA agreement 